\title{
Credit Default Swaps: The Good, The Bad And The Ugly
}

Terry Young, Pepperdine University, USA

Linnea McCord, Pepperdine University, USA

Peggy J. Crawford, Pepperdine University, USA

\begin{abstract}
Credit Default Swaps have been a major cause of problems to financial institutions during the current economic downturn. What is a CDS? Why was it developed? What went wrong? This paper discusses these questions.
\end{abstract}

Keywords: credit default swaps, swaps, financial crisis, financial reform

\section{INTRODUCTION}

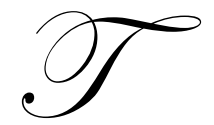

he current financial crisis has been an education in complex financial instruments. The first instrument that we became familiar with was the Collateralized Debt Instrument (CDO) or securities backed by pools of mortgages, student loans, credit card debt, corporate bonds, or other debt instruments. Now the instrument we are hearing about is the Credit Default Swap (CDS). This paper will explain the CDS, examine its purpose, and look at what went wrong - or the good, the bad and the ugly.

\section{THE GOOD}

A Credit Default Swap is not a traditional swap where two parties "swap" future cash flow streams. It is insurance-type contract which promises to cover the buyer of the contract's losses in the event of a default on the "insured" debt instrument. The CDS provides the buyer with protection by paying the face value of the bond or loan if a borrower fails to meet its debt obligations. On the other hand, the seller of the contract speculates that the company will not fail and generates a return (a stream of payments or premium) for providing the protection. Contracts typically are sold to protect against losses on mortgage securities, corporate bonds, and municipal bonds. Sellers include banks, insurance companies, hedge funds and other financial institutions.

The CDS transformed debt markets over the last decade. Investors desired higher yields, but not the additional risk generated by lending to less creditworthy borrowers. By providing a hedging instrument, the CDS allowed investors to increase their expected return, but limit additional risk by protecting them if borrowers failed to make debt payments. From the seller of the contract's point-of-view, the CDS was considered easy money. The economy was growing, corporate bankruptcies were infrequent, the housing market was booming, and consumers were spending. The CDS was seen as a low risk method to generate cash.

As the economy flourished, a flood of funds entered the CDS market. To accommodate these funds, the types of instruments covered by contracts expanded to include CDO which were often backed by pools of mortgages. In addition, the secondary market expanded as investors bought and sold CDS multiple times - making bets on the underlying firms' credit worthiness.

To illustrate how the market works, consider the following CDS. Western Asset Core Plus Bond Fund (a mutual fund with $\$ 14.6$ billion under management) sold a contract to Credit Suisse First Boston to insure $\$ 9$ million of Eastman Kodak bonds. If Kodak declares bankruptcy, Western Asset has to pay Credit Suisse some or all of the $\$ 9$ million in losses. For providing this protection, Western Asset receives 1.4 percent per quarter on the $\$ 9$ million from Credit Suisse. ${ }^{1}$ However, and this is where it begins to get "sticky," a CDS differs from traditional insurance 
in that financial institutions or other investor can insure bonds even if they don't own them. Neither Western Asset nor Credit Suisse owns the Eastman Kodak bonds. This means that technically any financial player can place a bet on Kodak's credit quality. This kind of speculation has pushed the value of outstanding CDS to $\$ 58$ trillion, much larger than the $\$ 6.2$ trillion in outstanding U.S. corporate debt. ${ }^{2}$

This illustration highlights the "good" side of a CDS - it provides protection against non-payment to one party and a return for providing this protection to the other party. However, it also illustrates a possible cause of the "bad" side of a CDS - neither party has to be directly involved in the underlying loan.

\section{THE BAD}

Credit Default Swaps are a good idea that, in some ways, went bad. Following are some of the risks created by the instruments and some of the questionable practices used by market participants.

Predatory Method: Credit default swaps changed the relationship between lenders and borrowers by sometimes pitting them against each other. ${ }^{3}$ Theoretically, creditors should attempt to keep solvent firms out of bankruptcy. However, with a CDS, some investors take a more predatory approach. Lenders (often hedge funds) who own a large number of CDS contracts may find bankruptcy more financially attractive than the solvency of the borrower. The exposure they hedged may provide them with higher returns from CDS payouts than from out-of- court restructuring plans. For example when SIX FLAGS, the theme-park operator, filed for Chapter 11 bankruptcy protection in June, it was the bondholders, rather than the credit market, who restrained its restructuring effort. Traditionally, if a firm (borrower) found itself in financial distress, bondholders often agreed to restructuring of the debt obligation as the expected return to the bondholder was higher if the firm could return to financial health than the return generated by bankruptcy. But with the protection provided by the CDS, the financial return of the hedged bondholders may be greater from forcing bankruptcy than from agreeing to a restructured debt obligation.

Liquidity Black Hole: Banks hold more than a trillion dollars worth of CDS and many consider them a ticking time bomb. As the economy turned from boom to bust, credit markets froze and corporate bankruptcies began to increase, and the housing market collapsed and foreclosures began to escalate. Credit insurers are vulnerable to shocks caused by a glut of defaults. The corporate default rate is expected by some to peak at 12.8 percent by the end of the year, up from 2.4 percent last year. ${ }^{4}$ Mortgage defaults and foreclosures are reaching record numbers. Defaults trigger CDS payments and this could cause a chain reaction which would be felt throughout the market. These claims are "notional" until insurers have to cover their positions. There is a danger that sellers of the protection may not have the funds to make good on these ever increasing losses. The buyers of CDS may face the loss generated by the default of the borrower plus the loss generated by the default of the seller of the "insurance" contract - the CDS.

Liability Coverage: Volatile bond prices may force swap holders to put up more collateral to cover their current liability. An example of this can be seen with the meltdown of Lehman Brothers. As fear spread in the market that Lehman would not be able to meet its debt obligations, the cost of its debt protection - CDS - began to rise rapidly. Lehman struggled to raise new capital to cover its CDS holdings, but was unable to and was forced to declare bankruptcy instead.

Counterparty Risks: There is the danger of counterparty risks where the company on the other side of the contract won't or can't pay up. Banks and insurance companies are regulated, but the Credit Default Swap market is not. Contracts can be traded and traded again, in the well developed secondary market, without anyone ensuring that the buyer has the resources to cover the losses in case of default. In other words, although a CDS is set up to look like insurance, it is something completely different. Insurance companies are required to set aside sufficient reserves of capital to cover losses on their obligations. This is not the case with the CDS. There is no requirement that money be set aside to ensure payment of financial obligations. It is a promise to transact only and no one regulates or monitors the amount of additional financial liability of any of the market participants or whether they have the financial reserves to make good on their promises. 
Higher Cost of Capital: Traditionally, corporate credit lines are tied to short term interest rates. However, several big banks such as Bank of America, Citibank, and JP Morgan Chase are linking credit lines to both short-term rates and Credit Default Swaps. ${ }^{5}$ Under the CDS based credit line, when the price of a CDS rises (the market thinks the company's financial health is deteriorating), the interest rate rises. In other words, the higher the risk the banks assume on these loans, the higher the cost of loan. Sounds logical as these new products give the lenders an extra layer of protection, but the borrowing company now has to deal with both the short-term interest rates and the CDS. At a time when banks are tightening credit and charging higher fees, companies do not have many options but to take the CDS linked loans. Instead, they are forced to accept potentially a higher cost of funds in this uncertain economic period. There is a danger that credit, which is the lifeblood of the economy, will continue to shrivel as there will be less credit flowing into the system.

\section{THE UGLY}

Credit default swaps became popular in the late 1990s as a way to make it easier for Wall Street to bundle and package an ever more complex array of debt securities. The banks hired the ratings agencies to obtain AAA ratings for these complex debt securities that could then be sold to mutual funds, pension funds, insurance companies and other investors in the U.S. and around the world. The growth of the CDS market closely coincided with efforts to stimulate the economy following the downturn that began in early 2001. To revive the economy, the U.S. Federal Reserve under Chairman Alan Greenspan, dramatically lowered interest rates to around 1 percent and kept the rates low for a very long time. This fueled a housing boom and bubble in which home prices skyrocketed. The rapid increase in home prices encouraged homeowners to refinance and withdraw equity to support their spending habits, and speculators to borrow and flip properties to generate returns. Securitization or selling a CDO backed by pools of home mortgages (which has been the typical practice for decades) and Credit Default Swaps which provided "insurance" against losses on the CDO generated enormous fees for the investment banks, banks, mortgage companies, Fannie Mae and Freddie Mac. And, the CDS market ballooned. ${ }^{6}$

The CDS was created to reduce the risk of financial loss caused by default on a loan obligation - a typical corporate bond or a complicated financial instrument like a collateralized debt obligation. However because of the risks and practices listed above, the CDS could increase the risk of loss associated with default substantially. But perhaps an even greater risk is what occurred during the housing bubble - a failure by some institutions to follow normal underwriting standards for the issuance of debt. When the bubble burst and the housing market crashed, sub-prime mortgages and exotic mortgage instruments (interest only and low teaser rate mortgages for example) began to default. These exotic mortgage instruments had allowed borrower to get into the housing market who would have been excluded by traditional qualification standards. An old truth was recognized - it doesn't matter how pretty the package is if the gift inside is broken. That is, no matter how complex the CDO is or how high its credit rating, if the pooled loans are of low quality, default is likely. The wave of defaults hit the sellers of CDS such as banks and insurance companies, and the purchasers of CDO and CDS such as hedge funds, pension funds, and the giant mortgage agencies Fannie Mae and Freddie Mac like a tsunami. It appears that the CDS often did not protect against the risk of loss from default, but instead enabled some market participants to gamble with other people's money. ${ }^{7}$ Because the CDS market was unregulated, it became an unknown force in the credit markets creating unknown instability and risk. Few understood how interconnected financial institutions had become because CDS contracts were sold and resold with no assurance the parties that accepted the premiums for the various CDS actually had the resources to pay on these contracts. As a result, “... the credit markets froze when [Lehman Brothers], once the fourth-largest U.S. investment bank, collapsed in the world's biggest bankruptcy"... and its CDS contracts could no longer be honored. ${ }^{8}$

The deficiencies in the CDS market played out with devastating consequences in the near bankruptcy of the one of the largest insurance companies in the world, American International Group (AIG). As of today, the AIG debacle has cost the American taxpayers more than $\$ 182$ billion and Credit Default Swaps played a large part in the federal government's decision to bail out AIG in September 2008. The “... Federal Reserve [had] concluded that if AIG failed and defaulted on its swaps, [it would have thrown] the liability for the insured securities onto the swaps' counterparties, [and] the result could [have been] a daisy chain of failures across the international financial system." 
How had this happened? AIG, as an insurance company, was responsible for investing its customers' premiums in liquid assets so that those assets would be available to pay future claims. Historically, a company like AIG would invest in safe investments like Treasuries. However, during the years of the booming economy when defaults on debt were rare and returns on safe securities were very low, banks, hedge funds and insurance companies like AIG began to see selling CDS contracts as a better way to obtain higher returns with minimal risk. Instead of buying and selling bonds with their customers' money, companies found it easier, quicker and more lucrative to simply buy and sell CDS contracts. Because of CDS, bond trading was transformed "into a highly leveraged, high velocity business." 10

When Lehman Brothers failed in 2008 triggering a global credit meltdown and real estate prices declined dramatically reducing the value of mortgage-back securities, AIGs credit rating was downgraded. With the loss of its AAA credit rating, AIGs CDS counterparties demanded dramatic increases in the collateral AIG was required to pay to its CDS counterparties. When AIG was unable to provide the $\$ 100$ billion in collateral required under the estimated $\$ 450$ billion in CDS contracts it had written, the federal government stepped in and loaned it $\$ 85$ billion in American taxpayers' money. The government felt this was necessary to prevent a global financial meltdown in credit resulting from cascading failures in CDS payments from one financial institution to another.

In the fourth quarter of 2008, AIG lost more than $\$ 60$ billion, the largest quarterly loss in the history of American business. As of today, the federal government has bailed out AIG three more times. George Soros, the billionaire investor, suggested that CDS contracts should be outlawed because they are "truly toxic. It's like buying life insurance on someone else's life, and owning a license to kill." 11

\section{FINANCIAL REFORM}

The Securities and Exchange Commission estimates that credit default swaps made up about $\$ 60$ trillion of the $\$ 600$ trillion credit derivatives market. The Bank of International Settlements, often referred to as the central bankers' central bank, puts the size of the global credit derivatives market much higher at about $\$ 1.2$ quadrillion. No one knows for sure how large a market this is because currently credit derivatives are unregulated and are not traded on an exchange. Because these numbers are so huge, it is no wonder that in 2002 Warren Buffet has referred to credit derivatives as "financial weapons of mass destruction." As early as 1997, some regulators began to worry about the size of the market and the lack of regulation. In testimony before Congress, the head of the Commodity Futures Trading Commission (CFTC), Brooksley Born, warned about the rising threat of these derivatives. She was promptly silenced by Federal Reserve Chairman Alan Greenspan, Treasury Secretary Robert Rubin and Assistant Deputy Secretary Larry Summers. ${ }^{12}$ Instead of heeding the warning, Senator Phil Gramm spearheaded the passage of the 2000 Commodity Futures Modernization Act, which prevented the CFTC from regulating over-the-counter derivatives such as credit-default swaps. ${ }^{13}$ Some market observers believe this bill is a major cause of the near collapse of the financial markets.

The Bush and Obama Administrations reacted to the financial crisis by pouring billions of dollars into banks, insurance companies, automobile manufactures etc. As the economy began to stabilize, the federal government turned from crisis mode to speculation as to the causes and development of plans to prevent this from happening again.

The Obama Administration announced its plan to overhaul the financial system in June 2009. The administration believes a major cause of the meltdown was "an absence of oversight." Therefore, a new agency would be created to regulate consumer financial products, police institutional investors and rein in the mortgage industry, and more power would be given to the Federal Reserve (Fed), the Treasury Department, and the Federal Deposit Insurance Company (FDIC). The Fed would become the top watchdog of the financial system and would regulate banks, brokerages, investors, and insurers deemed to big to fail. The Treasury Secretary would work with the Fed and chair a Council with the power to veto a decision by the Fed to make emergency loans to financial institutions. The FDIC would be given the power to seize and unwind not only banks, but any financial institution.

This was followed in August by a proposal for reforming the derivatives market. Under the Obama proposal "standardized" derivatives would be required to go through clearinghouses and be traded through an 
exchange or electronic trading system. Standardized derivatives would be subject to regulation by both the Securities and Exchange Commission and the Commodity Futures Trading Commission. They would also be subject to record-keeping requirements and trades and prices would have to be reported promptly. However, under this proposal customized derivative products would continue to remain unregulated. Gary Gensler, chairman of the Commodity Futures Trading Commission, warned Congress that the Obama proposal was too weak and would undermine the efforts of the regulators to combat fraud. Although Gensler helped draft the Obama Administration's proposals, he said that the final proposal contains too many exemptions which could be used by traders to avoid regulation. ${ }^{14}$

Several ideas and plan began making their way through Congress. House Financial Services Committee Chairman Barney Franks suggested banning "naked" CDS transactions, although market makers probably would be excluded from the ban. It is believed that about 80 percent of CDS contracts are held by speculators who do not own the underlying security. Representative Maxine Waters suggested a ban of all CDS contracts. In her view, this is the only effective way to curb the abuses that have become rampant in the CDS market. Representative Waters stated that unless CDS are completely banned, the same excesses could occur through the use of the exceptions for customized credit derivatives. Others have suggested setting higher capital and margin requirements. The Derivatives Trading Accountability and Disclosure Act, introduced by a group of democratic congressmen, would create an Office of Derivatives Supervision (ODS)within the Treasury Department with the power to set rules for derivatives trading and, similar to Obama plan, it would give Securities Exchange Commission (SEC) and Commodity Futures Trading Commission (CFTC) the ability to propose rules on margins and clearinghouses, but would give the ODS the right to override proposals and censure/suspend traders.

But "solutions" are not limited to Congress or the President. The International Swaps and Derivatives Association (a trade group) is working on a proposal to refine how CDS are documented and settled. Many are proposing a "Clearinghouse" similar to those in futures and options markets. The Fed took the first step in creating a clearinghouse by making the Intercontinental Exchange part of the Federal Reserve System to enable it to act as a central counterparty. However, Intercontinental is not the only institution anxious to create a clearinghouse. Both Chicago's CME group, and NYSE Euronext have shown interest in setting up a clearinghouse for the CDS as well.

\section{CONCLUSION}

Problems in the Credit Default Swap market could have a greater impact on the economy than the subprime meltdown. If bond insurance disappears or becomes more expensive, lenders may become more risk averse and lending standards tighten further. This could impact all borrowers from individuals applying for mortgages to municipalities borrowing to build schools.

Those who think the impact will be limited point to the global flow of funds and the improving economies in Asia, France and Germany. They point out that the CDS market survived - and some say "flourished" - during the last 12 months of global financial crisis.

However, the question remains if the federal government had not pumped billions of dollars into AIG and it had failed bringing down some of its counterparties including Goldman Sachs and some large European banks, where would the economy be today? And even more interesting, are there other AIGs out there waiting to be discovered?

In the end, Credit Default Swaps are probably not the cause of our current financial problems. Greed and irresponsible use of these - and other derivative instruments - caused the problems. Some of the criticisms on the CDS may be misguided. But nonetheless, the process of credit risk transfer needs some correction to prevent the unpredictable and painful consequences as experienced last Fall. New regulation will probably be passed - as early as the Fall, but what it will look like is still unclear. The only idea that seems to have fairly universal support is the idea of a clearinghouse. The question is will it be controlled by the government or run by private organizations.

We seem to be through the first chapter of the book, but it is too early to predict the ending. So, stay tuned! 


\section{AUTHOR INFORMATION}

Dr. Linnea B. McCord is an Associate Professor of Business Law at the Graziadio School of Business and Management of Pepperdine University.

Dr. McCord received a Bachelor of Arts degree from University of Sydney (including one year of law school at the University of Sydney Law School), a Juris Doctor degree from the University of Houston Law Center, and a Masters of Business Administration degree from the University of Texas at Austin.

Dr. Peggy J. Crawford has over 20 years business experience. She has consulted for a variety of firms including Klemm Consulting, Professional Development Institute, AT\&T, Sprint, and the Washington Redskins (her favorite job!). She was a founding partner of Eastwind Asset Management, a California investment firm, providing financial planning and portfolio management services for individual clients.

Dr. Crawford joined the faculty of the Graziadio School at Pepperdine University in 1997 after serving on the faculties of the University of Houston, Fordham University, and George Mason University. At Mason, she served as Chair of the Finance Department, Director of the Executive MBA, and Director of MBA Programs. At Pepperdine, she served as Associate Dean of Academic Affairs, Director of Accreditation and Learning Assurance, and Discipline Lead for Finance.

Dr. Crawford has published over thirty articles in a variety of practitioner and academic journals. Her research focuses mainly on corporate finance, capital markets, and real estate/mortgages topics including lease vs. buy decision, return on closed-end investment funds, risk profile of adjustable-rate mortgages, impact of the budget and trade deficits, Chinese currency policy, and speculation in oil markets.

Dr. Crawford received her PhD at Purdue University, in Finance and her BA at the University of Texas at Arlington, in History

Dr. Terry W. Young has over 15 years of business experience in Asia and the United States. She has extensive knowledge of the global marketplace, with a primary emphasis on Asia. Her consulting expertise encompasses global sourcing, business start-ups, and management in many industries, including food distribution, textile/garment, agriculture, and electronics. Additionally, she has significant experience in real estate development.

Dr. Young received her PhD at the University of Southern California, Los Angeles, MA at University of Southern California, Los Angeles, MA at University of Colorado, Boulder, and her BA at the University of Santo Thomas, Manila, Philippines

Dr. Young has more than 20 years of teaching experience at such institutions as Regis University, Denver, Colorado; California State University, Los Angeles; California State University, Long Beach, and the University of Southern California. She has been a full time faculty member at Pepperdine's Graziadio School of Business and Management since 1984 and is the 1994 recipient of the Luckman Distinguished Teaching Award.

Dr. Young is an experienced professor and economist and has dedicated the major part of her career to the education of others. She is experienced in the areas of U.S., European, Latin American, and Asian economies.

\section{ENDNOTES}

1 “Credit Default Swaps: Is Your Fund at Risk?” Business Week Online, 21 February 2008.

2 “Are You Exposed to CDS?" Business Week Online, 25 September 2008.

3 "No Empty Threat," The Economist Online, 18 June 2009.

4 “The Time Bomb in Corporate Debt," Business Week, 27 July 27 2009, p. 22-24.

5 "Biblio: Old Banks, New Tricks," Business Week, 12 August 2009, p. 20-23.

${ }^{6}$ Times Topics, “Credit Default Swaps," New York Times Online, 19 Aug. 19, 2009.

${ }^{7}$ Barr, Colin, "The Truth About Credit Default Swaps," Fortune at cnn.com online, 16 March 2009. 
${ }^{8}$ Leisin, Matthew, “Credit Swaps Investigated by U.S. Justice Department (update 3),” Bloomberg.com Online, 14 July 2009.

${ }^{9}$ Times Topics, "Credit Default Swaps," New York Times Online, Aug. 19, 2009.

${ }^{10}$ Davidson, Adam, "How AIG Fell Apart," Reuters Online, 18 September 2008.

11 “Soros Says Default Swaps Should be Outlawed," New York Times Online Dealbook, 12 June 2009.

${ }^{12}$ Katrina Vanden Heuvel, The Woman Greespan, Rubin \& Summers Silenced, The Nation Online, Oct. 9, 2008, http://www.thenation.com/blogs/edcut/370925, (accessed Aug. 29, 2009)

${ }_{13}$ Justin Fox, Phil Gramm Says the Banking Crisis Is (Mostly) Not His Fault, Time Online, Jan. 24, 2009 http://www.time.com/time/business/article/0,8599,1873833,00.html (accessed Aug. 29, 2009)

${ }^{14}$ Zachary A. Goldfarb, Derivatives Proposal is Too Sofe, Regulator Says, Washington Post Online, Aug. 20, 2009, http://www.washingtonpost.com/wp-dyn/content/article/2009/08/19/AR2009081903923.html (accessed Aug. 29, 2009) 


\section{NOTES}

